\title{
THE PRINCIPLE OF PEACEFUL COEXISTENCE OF TWO SYSTEMS AND THE IN- TERPRETATION OF ITS THEORETICAL SOURCES IN RESEARCH ON THE HIS- TORY OF THE COMMUNIST PARTY OF THE SOVIET UNION
}

\author{
Chengzhang Zou, Ph.D., Postdoctoral student, Beijing Normal University (Beijing, China) \\ https://orcid.org/0000-0002-6425-3811 \\ email: 787234243@qq.com
}

Received: May 12, 2021

Approved for printing: May 31, 2021

Published: June 21, 2021

Chengzhang Zou (2021). The principle of peaceful coexistence of two systems and the interpretation of its theoretical sources in research on the history of the Communist Party of the Soviet Union. Bulletin of Taras Shevchenko National University of Kyiv. Philosophy, 2(5), 64-69. https://doi.org/10.17721/2523-4064.2021/5-7/8

\begin{abstract}
The article presents the results of the author's study of the interpretation of the theoretical sources of the principle of peaceful coexistence of two systems in Soviet studies of the second half of the $20^{\text {th }}$ century, devoted to the history of the Communist Party of the Soviet Union. The author established a chronological framework for studying the principle of peaceful coexistence of two systems in Soviet historiography, and revealed Soviet historiographic markers of this principle in the corpuses of the works of Karl Marx, Friedrich Engels and Vladimir Ulyanov (Lenin). The article also presents a historical description and analysis of the way Soviet historians of the party interpreted the principle of peaceful coexistence of two systems in the works of Karl Marx and Friedrich Engels. The author identified the historical features of Soviet historians' interpretation of the principle of peaceful coexistence of two systems in the works of Vladimir Ulyanov (Lenin), systematized approaches to the interpretation of the theoretical sources of the principle of peaceful coexistence of two systems that were formed in Soviet studies on the history of the Communist Party of the Soviet Union, revealed their structural features, and also developed a model for their typology.
\end{abstract}

Keywords: the principle of peaceful coexistence of two systems, the history of Marxism, Soviet Marxism, the history of the Communist Party of the Soviet Union.

\section{Introduction}

In order to better understand the communist principle of "peaceful coexistence" it is necessary to turn to the literature of the Soviet period, such a methodological approach will provide a proper understanding of this phenomenon. For example, in the Philosophical Encyclopedic Dictionary (1983) there is an article devoted to the concept of "peace", and there is a separate article devoted to the concept of "peaceful coexistence". It is obvious that the very fact of the appearance of the second article testifies to the importance of these ideas not only for philosophy, but also for the worldview of Soviet people and ideology. This article defines: "PEACEFUL COEXISTENCE, is a type of relations between states with different societies, systems, which presupposes: rejection of war as a means of resolving disputed issues between states, their resolution through negotiations; equality, mutual understanding and trust between states, consideration of each other's interests; non-interference in internal affairs, recognition for each people of the right to freely choose their socioeconomic and political system; strict respect for the sovereignty and territorial integrity of all countries; development of economic and cultural cooperation based on equality and mutual benefit. The policy aimed at establishing and developing this type of relations between states is called the Policy of Peaceful Coexistence" (Philosophical Encyclopedic Dictionary, 1983: 373). This means that for Soviet ideologists, this concept determined the type of relations between states with different social systems without a declaration of war. As 
a political concept, it began to be used from the early 1920s to define relations between the Soviet Union and other states that were not yet ripe for the idea of a "world proletarian revolution" (Lenin, 1969a: 230-231). Thus, peacetime was considered temporary, it was the time of recovery after the Civil War before further revolutionary actions in the world. Initially, Soviet foreign policy was in line with the doctrine of the Comintern. This international organization, according to the idea of V. I. Lenin, in the period from the 1920s to the 1940s, united the communist parties of various countries: "the Union of workers of the whole world striving to establish Soviet power in all countries". The unification of the communist parties strengthened the polarity of the political map of the world, dividing countries into ideologically correct and, accordingly, incorrect, hostile. On the other hand, the Soviet government was initially faced with the need to work to establish diplomatic and economic relations with the rest of the world. However, almost immediately, policy, especially the foreign policy of the USSR, became more pragmatic, the country's leadership understood the importance of external contacts. Since the 1930s, there has been not only tolerance for capitalist countries, not just coexistence, but also beneficial interaction. These traits emerged during World War II. In the philosophical dictionary, this is clearly stated: "Peaceful coexistence is a form of the class struggle between socialism and capitalism in the international arena, but a specific form. Because, firstly, the struggle is waged between the ruling classes, each of which has the fullness of state power, and, secondly, the antagonistic conflict of two opposing socio-economic systems is transferred from the idea of war clashes into the idea of economic competition, comparison of political systems and ways of life, confrontation of ideologies. Organic interconnection, unity of struggle and cooperation is a characteristic feature of peaceful coexistence, a source of its internal contradictions, a constant stimulus for the search for mutually acceptable solutions that exclude military conflicts" (Philosophical Encyclopedic Dictionary, 1983: 373). In the middle of the $20^{\text {th }}$ century, J. V. Stalin and other Soviet leaders have repeatedly stated that ideological differences do not prevent the development of cooperation with the Western States. We find confirmation of this in the Foreign Policy Documents of the USSR: "Reality itself led us to the need to create lasting relationships between the government of workers and peasants and the capitalist governments" (USSR foreign policy documents, 1958: 639). The Soviet leadership developed the ideology of peaceful coexistence of the two systems and the conditions of friendly competition. These ideas, especially in the context of the Cold War, acquired an exclusively propagandistic character, which meant that they were ephemeral.

\section{Hronological framework for the study of the principle of peaceful coexistence of two systems in Soviet historiography}

In the period after the October Socialist Revolution of 1917 and before the formation of the USSR in 1922, there was a socialist state - the Russian Socialist Federative Soviet Republic. During this period, a separate peace treaty was signed in the city of Brest-Litovsk (March 3,1918) between representatives of the Soviet Russia (Bolshevik government of Russia) and the Central Powers, which ensured the withdrawal of the RSFSR from the World War I. The Bolsheviks tried to influence the governments of the Triple Entente, their goal was to conclude a general peace. The well-known words "without annexations and indemnities" well reflect the goals of Soviet Russia. The plans to achieve a universal democratic peace were not destined to come true, and internal party discussions began about the possibility of signing a separate treaty. Here the dialectical essence of Soviet thinking manifested itself, since the Soviet government tried to drag out all kinds of negotiations with the aim of agitating for a worldwide revolution. Unlike the formal logic of Aristotle, where two options of judgment are possible and the third is excluded, dialectical logic makes possible the unity of opposites. Therefore, for example, an ideology is possible that, at first glance, paradoxically combines pacifist ideas with the military ideas.

Marxism was largely based on German idealism, and if, for example, I. Kant proposed the idea of "Eternal Peace" in his political philosophy: "No state shall interfere by force in the constitution and government of another state. For what could justify it in taking such action? Could, forsooth, some offence which that state gives to the subjects of another state? Such a state ought rather to serve as a warning, because of the example of the evils which a state brings upon itself by its lawlessness. In general, the bad example given by one free person to another (as a scandalum acceptum) is no lesion of his rights" (Kant, 1897: 112). According to the Soviet philosopher, historian of philosophy I. S. Narskyi: "Kant points out that in international relations so far 
not law, but only force" (Narskyi, 1976: 176). G. Hegel believed that war is inevitable, moreover, it purifies peoples. Pondering over the history of wars, G. Hegel comes to the conclusion that the main reason giving rise to war is contradiction. He emphasized that contradiction exists both in nature and in society, it is the source of all movement and development. Once states exist, then there are contradictions between them, leading to conflicts and wars. A peculiar result of the development of ideas was summed up by V. I. Lenin, he wrote: "As applied to wars, the basic tenet of dialectics, so shamelessly distorted by Plekhanov to please the bourgeoisie, is that 'war is simply the continuation of politics by other' (namely violent) 'means'. This is the formulation of Clausewitz, one of the great writers on military history, whose ideas were fertilized by Hegel. And this was always the point of view of Marx and Engels, who viewed each war as a continuation of the policy of the given, interested powers - and different classes within them - at a given time" (Lenin, 1969b: 224).

The early years of the existence of the Soviet country were determined mainly by the policy of V. I. Lenin, but over time, the leader's health deteriorated, and because of political intrigues, J. V. Stalin came to power, he contributed to the idea of peaceful coexistence. In the era of developed socialism, relations with a potential enemy deteriorated sharply, which greatly strengthened the ideological dichotomy of peace and war.

\section{Soviet interpretation of the principle of peaceful coexistence of two systems in the works by Karl Marx and Friedrich Engels}

The idea of peaceful coexistence of the two systems presupposes a clear definition of the concept of "nation", since the polar world of diametrically opposed ideologies is largely determined by this concept. In their research, S. V. Rudenko and V. Y. Vilkov come to interesting conclusions that the concept of a nation is so complex and multifaceted that the nation itself can be organized on the basis of any concept. As for the possibility of the existence of the Soviet nation, they write in their article De-Stalinization of the Concept of the Nation in Soviet Marxism in the Second Half of the $20^{\text {th }}$ Century (2020): "However, in the Soviet scientific discourse the name 'Historical and Economic Theory of the Nation' was not historically original or politically and ideologically authentic. Since it was Joseph Stalin (in his work 'Marxism and the National Question' (1913), on the basis of the fundamental criticism of the ideas of the Austro-Marxists Otto Bauer and Karl Renner, introduced the basic postulates of the Marxist concept of the nation and proposed such a definition, that the Soviet social scientists throughout the post-Stalin era, even in the wake of the anti-Stalinist moods in the 1950s and early 1960s, could not substantially 'supplement' or 'modernize'” (Rudenko \& Vilkov, 2020: 167168). Moreover, J. V. Stalin categorically added: "There is only one option left, to recognize that the Russian Marxist theory of the nation is the only correct one" (Stalin, 1952: 335).

Soviet ideology with its principles was largely based on philosophy, taking their methods, concepts, ideas, and systems: "During the period of the Soviet Union, philosophy was based on the principles developed by Karl Marx and Friedrich Engels. These principles, in turn, were developed in the writings of Vladimir Lenin" (Sobolievskyi, 2018: 100). Dialectics was the main philosophical method. "...the categories of Marxist dialectics, noted that they are the basic logical concepts that reflect certain general aspects of the laws of various processes that take place in nature, society, and thought" (Yarmolitska \& Gan, 2020: 100). In the opinion of Soviet political scientists, K. Marx and F. Engels put forward a number of important provisions on the foreign policy of the working class and international relations of the future socialist society (Marx \& Engels, 1955: 445). In his dissertation for the degree of Doctor of Historical Sciences Lenin's principle of peaceful coexistence of two systems and the struggle of the CPSU and the Soviet government for its implementation at the present stage (1953-1956) (1957) researcher of the Kiev State University named after T. H. Shevchenko M. S. Zolotarev writes: "The founders of scientific socialism were fully aware of the fact that a sincere and consistent policy of peace and friendship between peoples can only be pursued by a society that emancipated labor, in other words, a socialist society. They predicted with prophetic power that to the extent that the exploitation of man by man is abolished, the exploitation of one nation by another will be abolished and the hostile relations between nations will fall" (Zolotarev, 1957: 1). Thanks to web archives with digitized dissertations, it is now possible to work with digital copies of original texts that were previously difficult to access. For example, the Soviet dissertations of the 1950s, which contain a unique vision of the theoretical component of the issue of 
peaceful coexistence. The researcher comes to such conclusions that combine the idea of peaceful coexistence of two systems, admission of political mistakes, personality cult and others: "Long-term cooperation between the states of the two systems in the past and, especially, during the World War II, has convincingly confirmed that this cooperation can and should be continued in the settlement of war conditions. However, such a prospect for the development of international relations was not included in the plans of the ruling circles of the imperialist states. Their policy 'from a position of strength' has exacerbated relations between countries to such an extent that it has become the greatest danger to the cause of peace... The Central Committee of the CPSU and the Soviet government were not afraid to tell our people about the mistakes that our diplomacy made in the atmosphere of the cult of personality... Following Lenin's behests, the Party and the Government are pursuing a deeply principled and at the same time flexible foreign policy aimed at strengthening cooperation between peoples" (Zolotarev, 1957: 328).

\section{Soviet interpretation of the principle of peaceful coexistence of two systems in the body of works of Vla- dimir Ulyanov (Lenin)}

In a famous conversation with the leader of the American Republican Party Harold Stassen in April 1947, J. V. Stalin said: "For the first time, the idea of cooperation between the two systems was expressed by Lenin. Lenin is our teacher, and we Soviet people are Lenin's students. We have never retreated and will not retreat from Lenin's instructions" (Stalin, 1997: 58). It is extremely curious that the complete collected works of J. V. Stalin have been published for more than half a century, for example, volumes 1-13 were prepared by the Marx-Engels-Lenin Institute in 1946-1952, and volumes 14-18 were prepared and published under the editorship R. I. Kosolapov in 1997-2006.

In his works, V. I. Lenin argued that the irreconcilability of the class interests of the world bourgeoisie and the victorious proletariat cannot be an insurmountable obstacle to peaceful relations between socialist and capitalist countries: "The development of the concept of peaceful coexistence was one of the greatest achievements of the political theory of Leninism" (Philosophical Encyclopedic Dictionary, 1983: 373). The Leninist principle of peaceful coexistence of the two systems was also mentioned in The Declaration of the Conference of Representatives of Communist and Workers' Parties of Socialist Countries, November 14-16, 1957. The Declaration describes the fundamental changes in the world that took place in the middle of the century, how the alignment of forces changed. Because of World War II, some countries that were leaders in the world economy and politics lost their primacy, giving way to other countries that were able to expand the economy and gain political influence. The declaration confirmed the unanimity of the parties represented at the conference in assessing the international situation. The meeting was attended by representatives of the Albanian Party of Labor, the Bulgarian Communist Party, the Hungarian Socialist Workers' Party, the Workers' Party of Vietnam, the Socialist Unified Party of Germany, the Communist Party of China, the Workers' Party of Korea, the Mongolian People's Revolutionary Party, the Polish United Workers' Party, the Romanian Workers' Party, the CPSU, The Communist Party of Czechoslovakia; It was also fully approved by all the communist parties of other countries of the world (Documents of the conferences of representatives of the communist and workers' parties held in Moscow in November 1957, 1957). Pointing to the existence of a military threat created by imperialism, primarily the United States and its partner countries, the Declaration emphasized that the struggle for peace is the primary task of the communist parties. This list of parties makes it possible to clearly understand the scale of influence of the ideas of Leninism, especially the idea of peaceful coexistence. In 2013, for the first time, unique, previously classified texts were published in a collection of documents related to the holding of international meetings of representatives of communist and workers' parties Heirs of the Comintern. International meetings of representatives of communist and workers' parties in Moscow (November 1957): Documents // Documents and materials of meetings and conferences of representatives of the communist and workers' parties (2013) presented the program documents of the international communist and workers' movement, adopted at these meetings: the Declaration and Manifesto of Peace with all options, amendments, editions. For the first time, the book publishes verbatim records of the Meetings and documents reflecting the historical and political context of the era when the Soviet Union positioned itself as a winner.

Soviet historians believed that the Soviet Union played a decisive role in the victory over fascism; this is a key event in ideology that determines all spheres of life in the second half of the $20^{\text {th }}$ century. After the end of 
the World War II, the political map of the World changed, which ideologists saw as another step towards the collapse of the colonial empires and the domination of world socialism. The most important role in world politics in the middle of the $20^{\text {th }}$ century was played by the appearance of weapons of mass destruction, with the appearance of missiles with nuclear weapons in the Soviet Union, according to ideologists, created a balance of power, a balance between two systems: capitalism and socialism.

\section{Conclusions}

For the socialist countries of the $20^{\text {th }}$ century, the model of relations was the principle of socialist internationalism, which grew out of the principle of peaceful coexistence. Class solidarity is a fundamental principle of political philosophy, it denies national characteristics in the face of a common problem, promotes mutual assistance of fraternal socialist states. Therefore, in the opinion of Soviet ideologists, the principle of peaceful coexistence of the two systems was determined. However, the West has criticized even such a simple and clear principle. For example, this principle of peaceful coexistence was considered a "fictitious", designed to conceal its militant plans from a potential enemy. There was also an opinion that such a principle is a tool for implanting revolutionary ideas in other states, to which Soviet ideology replied that a revolution cannot be implanted, it is a natural process in the history of society. However, there were also opposite opinions that this principle of peaceful coexistence of the two systems would slow down revolutionary processes in the world. The influence of German idealist philosophy with its dialectics made possible the existence of such contradictory ideas that were convenient for propaganda and the official political agenda. Many ideas of this principle remain relevant today, especially given the ongoing military conflicts in the world and the need to maintain peace in society.

\section{References}

Documents of the conferences of representatives of the communist and workers' parties held in Moscow in November 1957. (1957). Moscow.

Kant, I. (1897). Eternal Peace. The Advocate of Peace (1894-1920). Vol. 59. No. 5. PP. 111-116. URL: https://www.jstor.org/stable/25751039

Lenin, V. I. (1969a). Communist International. Complete Works: in 55 volumes. Vol. 38: March 1919 - June 1919. Moscow: Publisher Political Literature.

Lenin, V. I. (1969b). The collapse of the II International. Complete Works: in 55 volumes. Vol. 26: July 1914 August 1915. Moscow: Publisher Political Literature.

Narskyi, I. S. (1976). Kant. Moscow: Mysl.

Philosophical Encyclopedic Dictionary. (1983). Moscow: Soviet Encyclopedia.

Rudenko, S., Vilkov, V. (2020). De-Stalinization of the Concept of the Nation in Soviet Marxism in the Second Half of the 20th Century. Politické Vedy. Vol. 23. No. 4. P. 160-195. https://doi.org/10.24040/politickevedy.2020.23.4.160-195

Sobolievskyi, Y. (2018). Soviet and Ukrainian Studies of American Philosophy: Translation of Philosophical Texts. Future Human Image. Vol. 9. P. 100-106. http://doi.org/10.29202/fhi/9/10

Stalin J. V. (1997). Works. Vol. 16. Moscow: Publishing house "Pisatel".

Stalin, J. V. (1952). National Question and Leninism. Answer to the Comrades Meshkov, Kovalchuk and others. Works. Vol. 11. Moscow: Publisher Political Literature.

USSR foreign policy documents. Vol. 2. January 1, 1919 - June 30, 1920. (1958). Moscow: Gospolitizdat.

Yarmolitska, N., Gan K. (2020). Kharkiv Research School in Ukrainian Philosophy of Soviet Period: Social, Political and Philosophical Researches. Ukrainian Policymaker. Vol. $7 . \quad$ P. 97-105. https://doi.org/10.29202/up/7/11

Zolotarev, M. S. (1957). Lenin's principle of peaceful coexistence of two systems and the struggle of the CPSU and the Soviet government for its implementation at the present stage (1953-1956). Candidate's thesis. Kyiv. 


\section{ІНТЕРПРЕТАЦІ ТЕОРЕТИЧНИХ ДЖЕРЕЛ ПРИНЦИПУ МИРНОГО СПІВІС- НУВАННЯ ДВОХ СИСТЕМ У ДОСЛІДЖЕННЯХ З ІСТОРЇ̈ КОМУНІСТИЧНОЇ ПАРТІЇ РАДЯНСЬКОГО СОЮЗУ}

Ченгжанг Жоу, доктор філософї, докторант, Нормальний університет Пекіна (м. Пекін, Китайська Народна Республіка) https://orcid.org/0000-0002-6425-3811, e-mail: 787234243@qq.com

\section{Анотація}

Стаття презентує результати авторського дослідження інтерпретачї теоретичних джерел принципу мирного співіснування двох систем у радянських студіях другої половини 20 століття, присвячених історії Комуністичної партії Радянського Союзу. Автор встановив хронологічні рамки дослідження приниипу мирного співіснування двох систем у радянській історіографї, а також розкрив радянські історіографічні маркери иього принципу у корпусах прачь Карла Маркса, Фрідріха Енгельса та Володимира Ульянова (Леніна). Також стаття презентує історичний опис та аналіз способу інтерпретачіi радянськими істориками партї теоретичних розробок приниипу мирного співіснування двох систем у прачях Карла Маркса та Фрідріха Енгельса. Автор ідентифікував історичні особливості інтерпретачіі радянськими істориками приниипу мирного співіснування двох систем у роботах Володимира Ульянова (Леніна), систематизував підходи до інтерпретачї теоретичних джерел приниипу мирного співіснування двох систем, які сформувалися в радянських дослідженнях з історії Комуністичної партї Радянського союзу, також розробив модель іхньої типологізачї.

Ключові слова: принцип мирного співіснування двох систем, історія марксизму, радянський марксизм, історія Комуністичної партї Радянського Союзу.

Отримано: 12.05 .2021

Ухвалено до друку: 31.05 .2021

Опубліковано: 21.06.2021

Ченгжанг Жоу (2021). Інтерпретачія теоретичних джерел приниипу мирного співіснування двох систем у дослідженнях з історії комуністичної партії Радянського Союзу. Вісник Київського начіонального університету імені Тараса Шевченка. Філософія, 2(5), 64-69. https://doi.org/10.17721/2523-4064.2021/5-7/8 